\title{
Desain Bilik Sterilisasi "White Box"
}

\author{
Noor Hamidah $^{\mathrm{a}^{*}}$, Dwi Anung Nindito ${ }^{\mathrm{b}}$, Tatau Wijaya Garib ${ }^{\mathrm{a}}$, Waluyo Nuswantoro ${ }^{\mathrm{b}}$, Mahdi Santoso ${ }^{\mathrm{c}}$ \\ a Staf Pengajar di Jurusan/Prodi Arsitektur, Fakultas Teknik, Universitas Palangka Raya

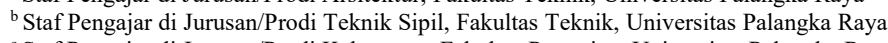 \\ ${ }^{\mathrm{c}}$ Staf Pengajar di Jurusan/Prodi Kehutanan, Fakultas Pertanian, Universitas Palangka Raya
}

\begin{abstract}
Keywords:
design

sterilization booth

condensing dispenser

\section{ABSTRACT}

The sterilization chamber is designed to sterilize the body using a filler formulation that is not harmful to the skin surface. Formulation, namely the composition of filler fluids (type, dose and amount) using substances that are safe for the body accordingly, certainly provides benefits. The use of the sterilization booth uses the correct and safe filling fluid. The sterilization chamber uses a mist nozzle sprayer (with the appropriate discharge) to spray the filling liquid so that the user is safe. This sterilization booth is named "White Box". This "White Box" research aims to design (functional and structural) and test (function test and performance test) on a system and mechanism for condensing the condensation of a humidifier that can fill the sterilization room optimally. The design method of the "White Box" sterilization booth uses a qualitative method with the following phases: (1) The preparation stage, namely the functional design and the structural design of the "White Box"; (2) The implementation stage is analyzing the use of tools and materials and making sterilization booths; (3) Post-implementation stage, namely testing the sterilization chamber, including the function test and performance test of the sterilization chamber. The design activity of the "White Box" sterilization booth was carried out by testing various variations of the prototype, including variations in the dimensions of the distribution pipe, the shape of the distribution pipe, and variations of the piping system. The validation process includes: (1) The diameter of the pipe against humidifier dew bursts; (2) The shape of the piping against humidifier dew spray; and (3) the length of the pipe passage to the humidifier dew spray.
\end{abstract}

Kata kunci:

rancang bangun

bilik sterilisasi

penyalur pengembunan

\section{ABSTRAK}

Bilik sterilisasi didesain untuk mensterilisasi tubuh dengan menggunakan formulasi zat pengisi yang tidak berbahaya bagi permukaan kulit. Formulasi yaitu komposisi cairan pengisi (jenis, takaran dan jumlah) menggunakan zat yang aman bagi tubuh yang sesuai, tentu memberi manfaat. Penggunaan bilik sterilisasi menggunakan cairan pengisi yang benar dan aman. Bilik sterilisasi menggunakan mist nozzle sprayer (yang debitnya sesuai) untuk menyemprotkan cairan pengisinya sehingga pengguna aman. Bilik sterilisasi ini diberi nama "White Box". Penelitian "White Box"ini bertujuan merancang (fungsional dan struktural) dan menguji coba (uji fungsi dan uji kinerja) pada sebuah sistem dan mekanisme penyaluran pengembunan dari alat humidifier yang mampu memenuhi ruang bilik sterilisasi secara optimal. Metode rancang bangun bilik sterilisasi "White Box" menggunakan metode kualitatif dengan tahap kegiatan meliputi: (1) Tahap persiapan yaitu rancangan fungsional dan rancangan struktural"White Box"; (2) Tahap pelaksanaan yaitu analisa penggunaan alat dan bahan dan Pembuatan bilik sterilisasi; (3) Tahap Pasca Pelaksanaan yaitu pengujian bilik sterilisasi antara lain uji fungsi dan uji kinerja bilik sterilisasi. Muatan kegiatan rancang bangun bilik sterilisasi "White Box" dilakukan dengan cara menguji coba berbagai variasi prototipe, meliputi variasi dimensi pipa penyaluran, bentuk pipa penyalur, variasi sistem perpipaan. Proses validasi yang dilakukan meliputi: (1) Diamater pipa terhadap semburan embun humidifier; (2) Bentuk pipa penyalur terhadap semburan embun humidifier; dan (3) Panjang lintasan pipa terhadap semburan embun humidifier.

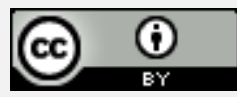

This is an open access article under the CC-BY license.

\footnotetext{
*Corresponding author.

E-mail: nhamidah04@gmail.com

https://doi.org/10.21831/inersia.v17i1.39497

Received 18 March 2021; Revised 15 April 2021; Accepted 28 April 2021

Available online 28 May 2021
} 


\section{Pendahuluan}

Sejak pandemi covid-19 menyebar ke Indonesia, langkah antisipasi untuk menekan peningkatan jumlah penderita virus covid-19 di Indonesia telah dilakukan pemerintah melalui berbagai kebijakan yang diterapkan di seluruh daerah [1]-[3]. Selain itu bilik sterilisasi dapat ditemui di beberapa tempat umum. Bilik sterilisasi digunakan untuk membunuh virus yang mungkin menempel di tubuh manusia [4]. Kandungan bahan-bahan kimia seperti disinfektan dapat membahayakan jika terkena pakaian atau selaput lendir, contohnya mata dan mulut. Jika dicermati secara bijak, sesungguhnya bilik diinfektan yang dimaksud di sini adalah bilik sterilisasi. Jika cairan pengisinya adalah cairan disinfektan, maka tentu akan berbahaya bagi permukaan tubuh [5]. WHO tidak menganjurkan penggunaan bahan disinfektan dalam penggunaan bilik sterilisasi apabila komposisi cairan disinfektan dapat berbahaya bagi kesehatan manusia [6]. Menurut [4] cairan disinfektan yang digunakan pada bilik sterilisasi maupun disemprotkan ke sejumlah fasilitas umum adalah cukup aman jika penggunaan Benzalkonium Chlorida, atau bahan yang digunakan untuk penyemprotan dalam dosis atau takaran yang tepat. Dalam penelitian [5], diketahui bahwa cairan disinfektan yang terdapat dalam bilik dan terpasang di sejumlah wilayah aman untuk tubuh manusia, asal campurannya benar [7]. Bahan aktif yang digunakan ialah benzalkonium chloride, yang masuk dalam golongan ammonium quartener. Bahan itu aman untuk manusia karena levelnya tingkat rendah [5].

Permasalahan umum pada bilik sterilisasi menggunakan mist nozzle sprayer (yang debitnya cukup besar) untuk menyemprotkan cairan pengisinya, sehingga pengguna merasa tidak nyaman karena permukaan kulit dan pakaian cenderung "basah kuyup" sehingga menimbulkan masalah baru, misalnya pengguna menjadi kedinginan dan akhirnya terserang flu (demam dan pilek). Permasalahan lain terkait optimalisasi sistem penyemprotan/ pengembunan sering dijumpai dalam mendesain bilik sterilisasi. Bilik sterilisaasi yang menggunakan alat misk maker (pengembunan/ kabut) misalnya humidifier, menimbulkan permasalahan pada sistem penyaluran pengembunan yang cenderung tidak optimal. Sifat zat cair (embun yang dihembuskan) agak sulit diatur melalui sistem saluran yang berkelok dan berubah luas penampangnya (menyempit atau melebar) [6].

Kelemahan kedua sistem penyemprotan tersebut di atas, sebagai pertimbangan perlu dilakukan rancang bangun sistem dan mekanisme penyalur pengembunan sebagai salah satu solusi dari bilik sterilisasi. Penelitian ini membuat komposisi cairan pengisi di bilik sterilisasi menggunakan zat yang aman bagi tubuh (jenis, takaran dan jumlah) yang sesuai, dan tentu saja akan memberi manfaat bagi manusia [6]. Tujuan utama penelitian antara lain : (a) merancang (fungsional dan struktural) sistem bilik sterilisasi "White Box"; (b) membuat bilik sterilisasi "White Box" berdasarkan rancangan fungsional dan struktural; (c) menguji fungsi dan uji kinerja bilik sterilisasi "White Box". Penelitian ini melakukan rancangan fungsional dan struktural, melakukan pendampingan pelatihan pembuatan bilik steriliasi pada masyarakat, membuat bilik steriliasai, dan melakukan uji coba sistem outlet dari beberapa variasi penyalur pengembunan untuk memperoleh optimalisasi pola hembusan embun/ kabut dari alat humidifier yang hanya memiliki satu arah. Bilik sterilisasi perlu dilakukan untuk uji fungsi dan kinerja.

Hasil uji fungsi yaitu uji prototipe dengan cara memvariasi dimensi penyaluran, bentuk penyalur dan sistem penyaluran yang tepat akan digunakan untuk pembuatan bilik sterilisasi [6]. Penelitian ini dapat memberikan manfaat antara lain: (1) Secara teoritis, penelitian ini dapat memberikan sumbangan ilmu bagi kajian sistem bilik sterilisasi, khususnya dalam mengaplikasikan penyaluran sistem pengembunan. Penelitian ini juga diharapkan dapat menjadi referensi dan wacana baru tentang sistem penyelur pengembunan bilik sterilisasi. (2) Secara praktis, penelitian ini dapat membantu masyarakat dalam membuat menggunakan bilik sterilisasi dengan cara mengoptimalkan sistem penyaluran pengembunan dari alat humidifier.

\section{Metode Penelitian}

Metode rancang bangun bilik sterilisasi "White Box" menggunakan metode kualitatif [8] dengan tahap kegiatan dilakukan di laboratorium Hidrologi dan Hidrolika Fakultas Teknik, UPR. Lokasi penelitian dilakukan di Kampus Fakultas Teknik Universitas Palangka Raya, Kota Palangka Raya. Alasan pemilihan lokasi kampus sebagai kawasan pusat pendidikan dan pemberi layanan akademik seperti tertera di Gambar 1 . Penelitian bilik sterilisasi "white box" dilakukan dengan tiga tahap yaitu: (a) tahap persiapan; (b) tahap pelaksanaan; dan (c) tahap pasca pelaksanaan.

Penelitian rancang bangun alat Teknologi Tepat Guna (TTG) yaitu bilik sterilisasi dilengkapi dengan fitur proses penyalur pengembunan dari alat humidifier yang 
disebut bilik sterilisasi "White Box" [6]. Penelitian dalam rancang bangun bilik sterilisasi "White Box" menggunakan alat antara lain: cutter, gerinda, gergaji dan gunting sebagai alat pemotong bahan, mesin bor sebagai alat pelubang bahan, solder sebagai alat penyambung bahan.

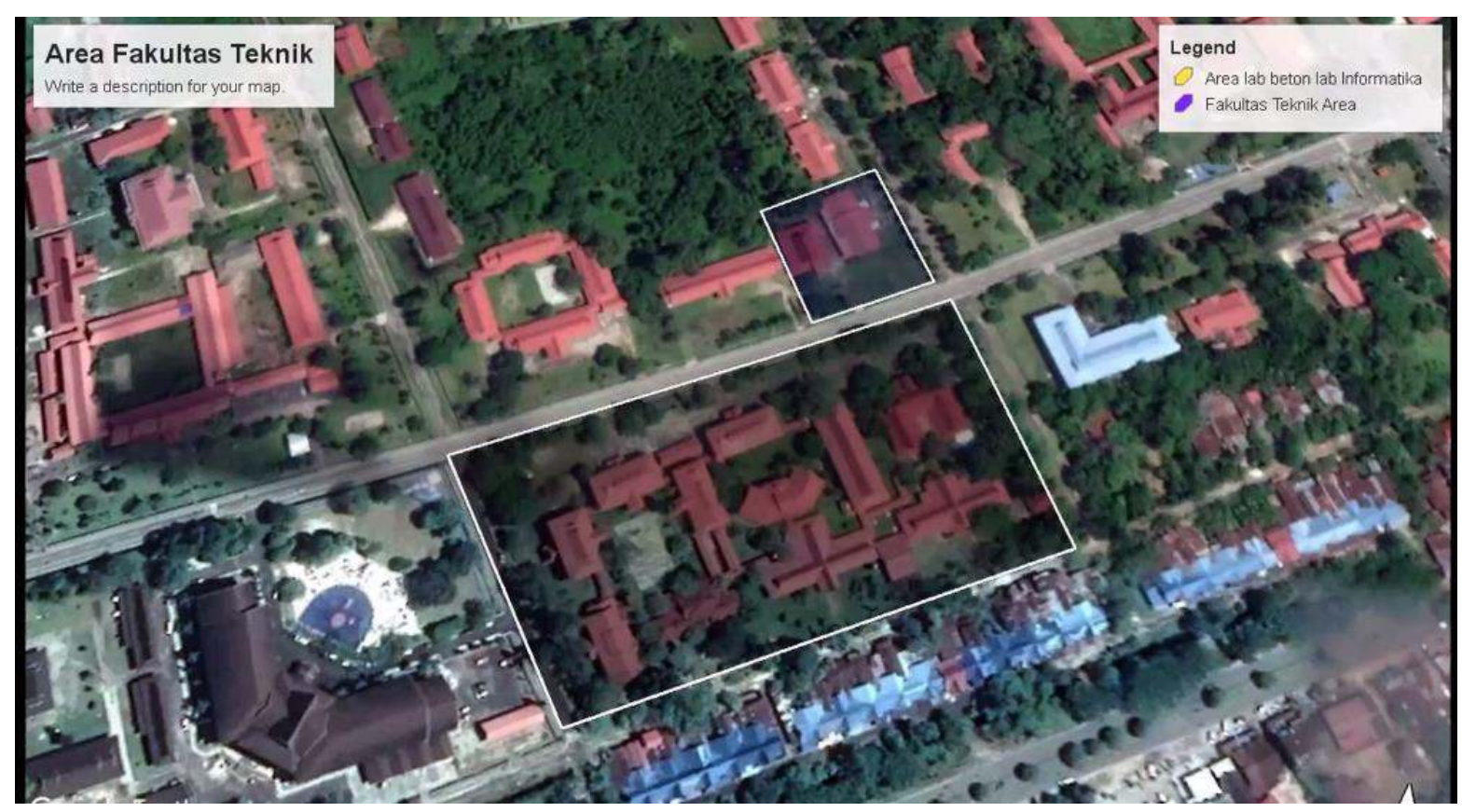

Gambar 1. Lokasi Penelitian Kampus Fakultas Teknik Universitas Palangka Raya, Kota Palangka Raya [6]

Bahan yang digunakan antara lain: (a) Mist Maker Humidifier (b) Bahan penyalur pengkabutan: pipa 4 dan 6-inch, fitting tee 6-inch, fitting tee 6-inch, reducer socket 8x6 inch, reducer socket $6 \times 4$ inch. (c) solder sebagai alat penyambung bahan. Bahan yang digunakan antara lain: fitting tee 6 inchi, reducer socket $8 \times 6$ inchi, reducer socket $6 \times 4$ inchi. (c) Bahan pembuatan rangka bilik sterilisasi: besi siku lubang, plat sudut siku lubang, mur baut $8 \times 15$ dan ring baut $8 \times 15$. (d) Bahan Sensor Gerak PIR Infra Merah. (e) Bahan komponen sensor halangan, yaitu: Relay module 1 channel untuk Arduino dan Module IR Infrared Obstacle sensor halangan. (f) Bahan kelistrikan: kabel, stop kontak, steker, timah solder dan cable ties; (g) Penutup bilik sterilisasi: plastik PVC, korden plastik, rel tirai, dan alas bilik sterilisasi. (h) Bahan tempat cairan antiseptik : galon kran 12 liter, kran PVC 3/4 inch, selang 3/8 inchi.

\section{Analisis dan Pembahasan}

\subsection{Analisa Proses Penelitian}

Pada penelitian Rancang Bangun Bilik Sterilisasi "white box" dilakukan dalam beberapa tahap kegiatan antara lain: Tahap Persiapan yang terdiri dari: (a) mengumpulkan data-data atau literatur tentang hasil penelitian dan publikasi yang relevan dan terkini; (b) mempersiapkan data peta lokasi yaitu foto udara (peta di google earth) sebagai panduan tempat lokasi penempatan hasil penelitian [6]. Tahap pelaksanaan yaitu pembuatan bilik sterilisasi "White Box", antara lain: (a) Mendesain bentuk rancangan struktural dan fungsional bilik sterilisasi "White Box"; (b) Mempersiapkan alat dan bahan yang diperlukan untuk bilik sterilisasi "White Box", (iii) Melakukan perakitan Bilik sterilisasi "White Box" dan proses penyalur pengembunan dari humidifier yang optimal. Tahap pascapelaksanaan yaitu uji bilik sterilisasi "White Box" dengan melakukan variasi dimensi pipa penyalur, variasi bentuk pipa penyalur dan variasi sistem perpipaan. Pengujian yang dilakukan antara lain: (a) Uji fungsi dilakukan dengan mengacu pada pengujian bilik sterilisasi "White Box" berdasarkan berbagai variasi percobaan. (b) Uji kinerja dilakukan setelah lolos proses uji fungsi. Jika uji kinerja gagal, maka proses rancang bangun dilakukan pengulangan dengan melakukan uji fungsi.

\subsection{Analisa Rancangan Fungsional}

Penelitian rancangan bangun bilik sterilisasi "White Box" ini dilakukan dengan tujuan fungsional melakukan optimalisasi sistem penyalur pengembunan yang dihasilkan alat humidifier seperti tertera pada Gambar 2. 


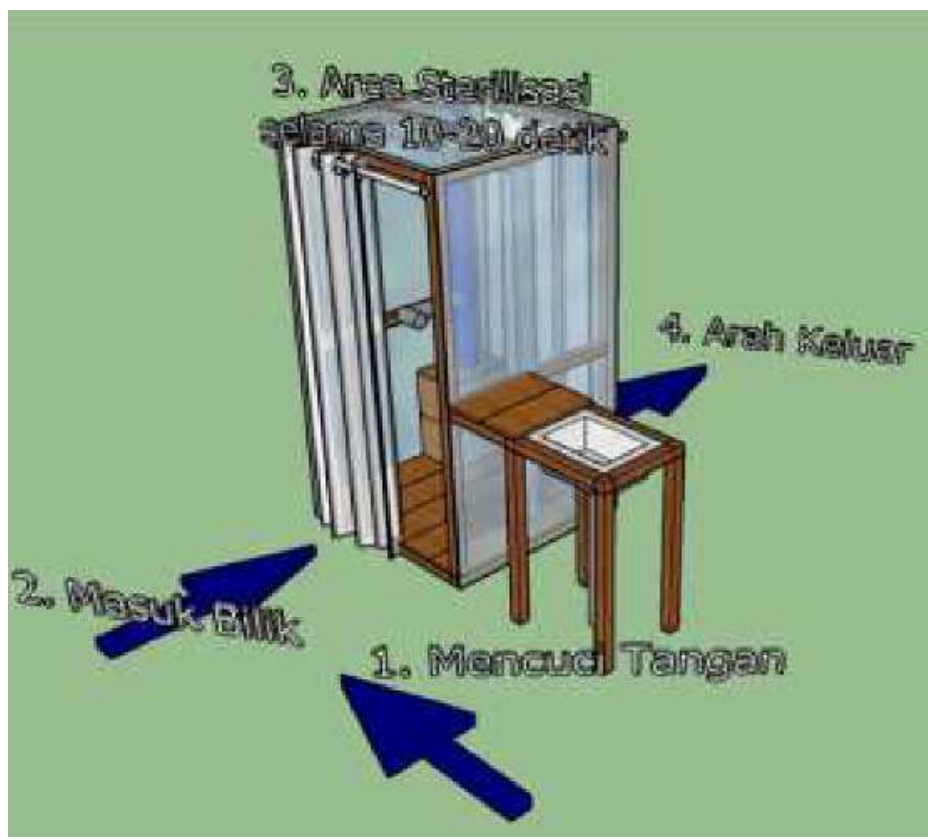

(a)

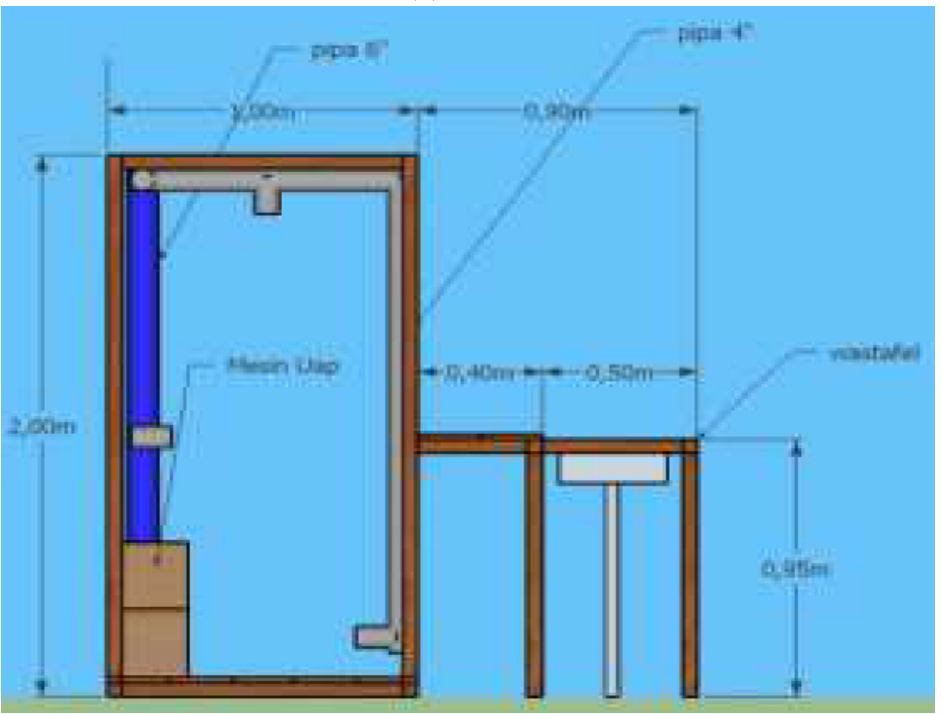

(b)

Gambar 2. Bilik Sterilisasi "White Box"

(a) Gambar Perspektif "White Box"; (b) Potongan Melintang "White Box" [6]

\subsection{Analisa Rancangan Struktural}

Pada saat pengguna masuk ke bilik sterilisasi "White Box", maka sensor gerak/halangan akan merespon dan secara otomatis menghidupkan humidifier (yang menghasilkan pengembunan) dan disalurkan ke sistem perpipaan dan dikeluarkan ke sistem lubang (outlet system) sehingga menyebar ke bilik dan mengenai seluruh tubuh pengguna. Metode dan alur penelitian rancang bangun bilik sterilisasi "White Box".

Penelitian rancangan bangun bilik sterilisasi "White Box" ini dilakukan dengan dua tujuan yaitu: (a) tujuan fungsional melakukan optimalisasi sistem penyalur pengembunan yang dihasilkan alat humidifier. (b) Rancangan Struktural, bilik sterilisasi "White Box" meliputi: dimensi; bentuk, dan sistem perpipaan. Komposisi ketiga komponen rancangan struktural ini diujicobakan sehingga membentuk sebuah sistem yang optimal dalam menyalurkan pengembunan yang dihasilkan alat humidifier. Rancang bangun bilik sterilisasi ini menggunakan satu jenis alat pengembunan (humidifier), sekaligus menjadi parameter tetap dalam penelitian ini. 
Proses penyaluran pengembunan ditampung dalam sebuah bilik yang memungkinkan pengguna untuk masuk di dalamnya dan melakukan proses sterilisasi. Bilik sterilisai "White Box" dilengkapi dengan satu pintu masuk pada bagian depan dan satu pintu keluar bagian belakang, sehingga pengguna hanya boleh melewati satu pintu masuk dan satu pintu keluar saja (one gate sistem).

\subsection{Pembuatan Bilik Sterilisasi}

Bilik sterilisasi "White Box" dibuat dan dirakit sedemikian rupa sehingga diperoleh bilik dan proses penyalur pengembunan dari humidifier bisa optimal seperti tertera di Gambar 3.

\subsection{Pengujian Bilik Sterilisasi "White Box"}

Pengujian bilik sterilisasi "White Box" dilakukan dengan melakukan variasi dimensi pipa penyalur, variasi bentuk pipa penyalur dan variasi sistem perpipaan seperti tertera di Gambar 4 sampai dengan Gambar 6.

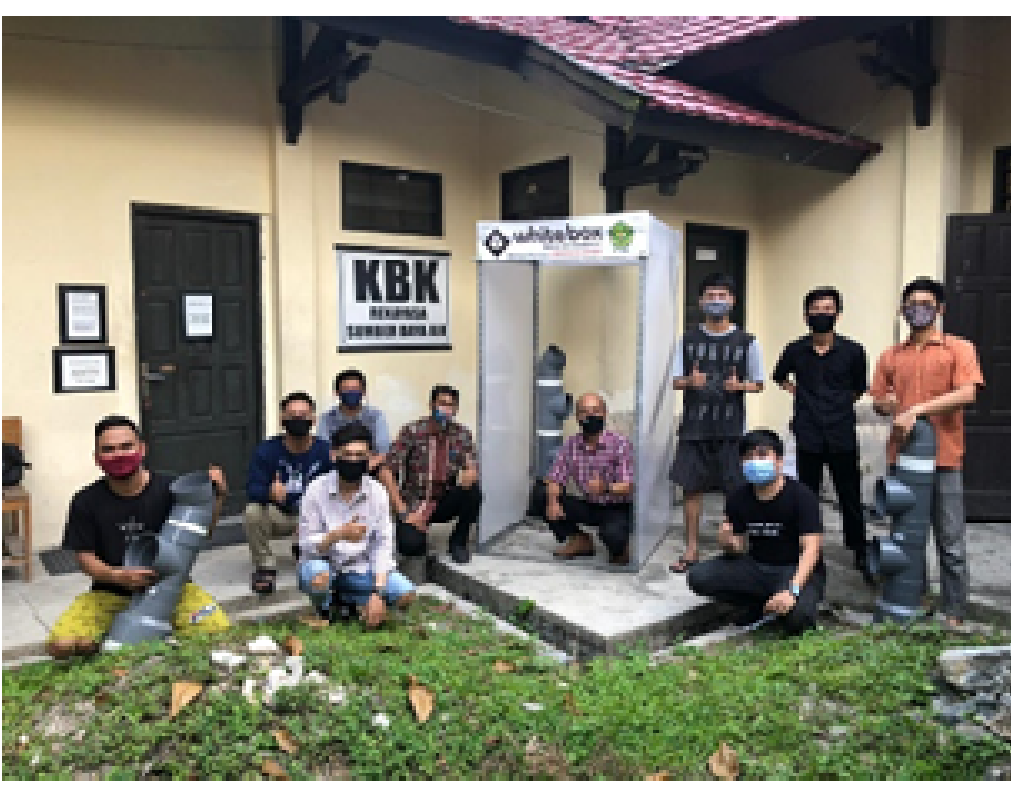

(a)

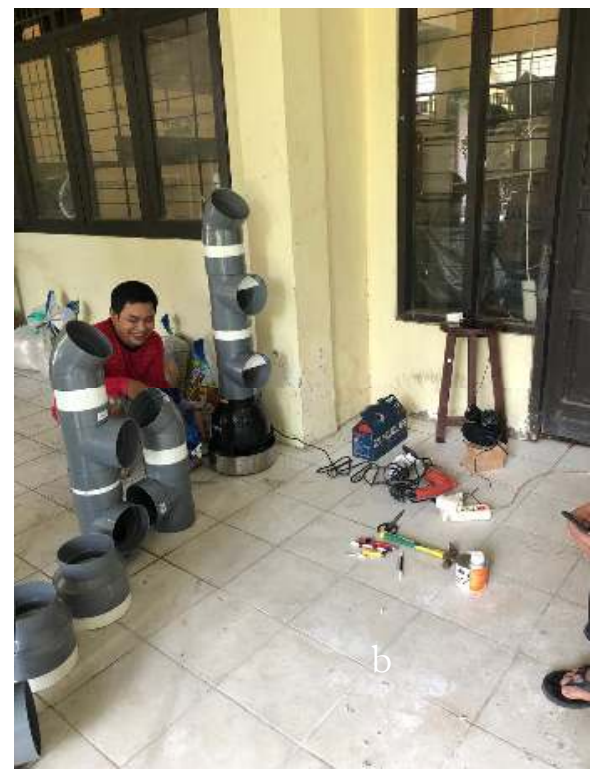

(b)

Gambar 3. Pembuatan Bilik White Box: (a) pemasangan rangka bilik; (b) Pemasangan Alat Pengembunan [6]

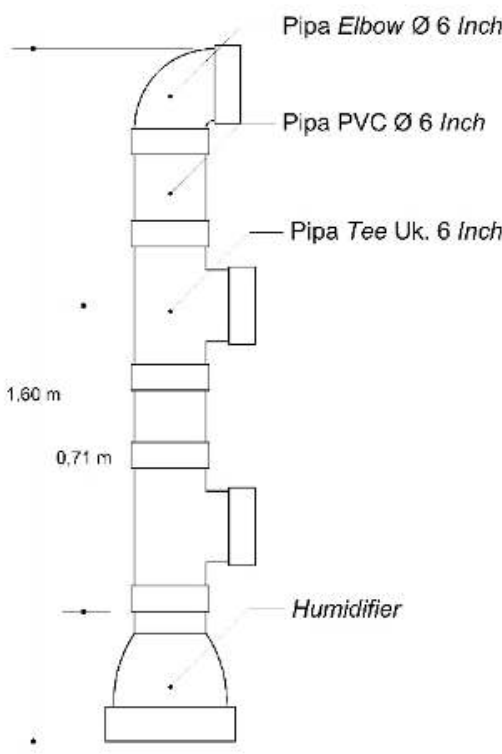

(a)

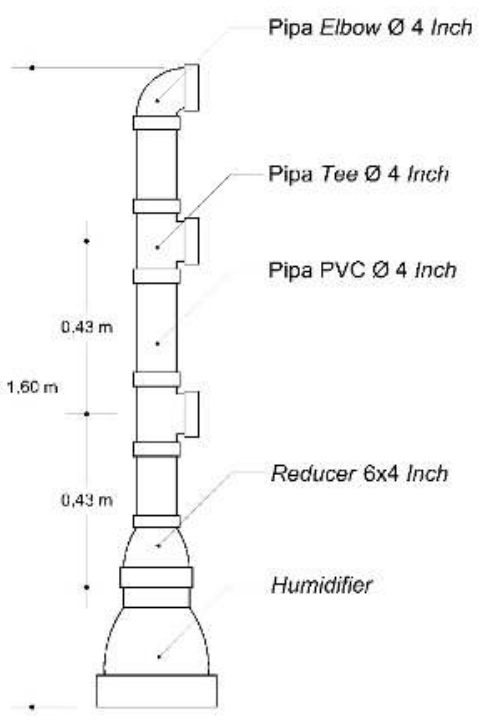

(b)

Gambar 4. Variasi Dimensi Pipa Penyalur (a) Pipa dengan Ukuran Sesuai Mulut Humidifier (b) Pipa Mengecil dengan Ukuran Lebih Kecil dari Mulut Humidifier [9] 


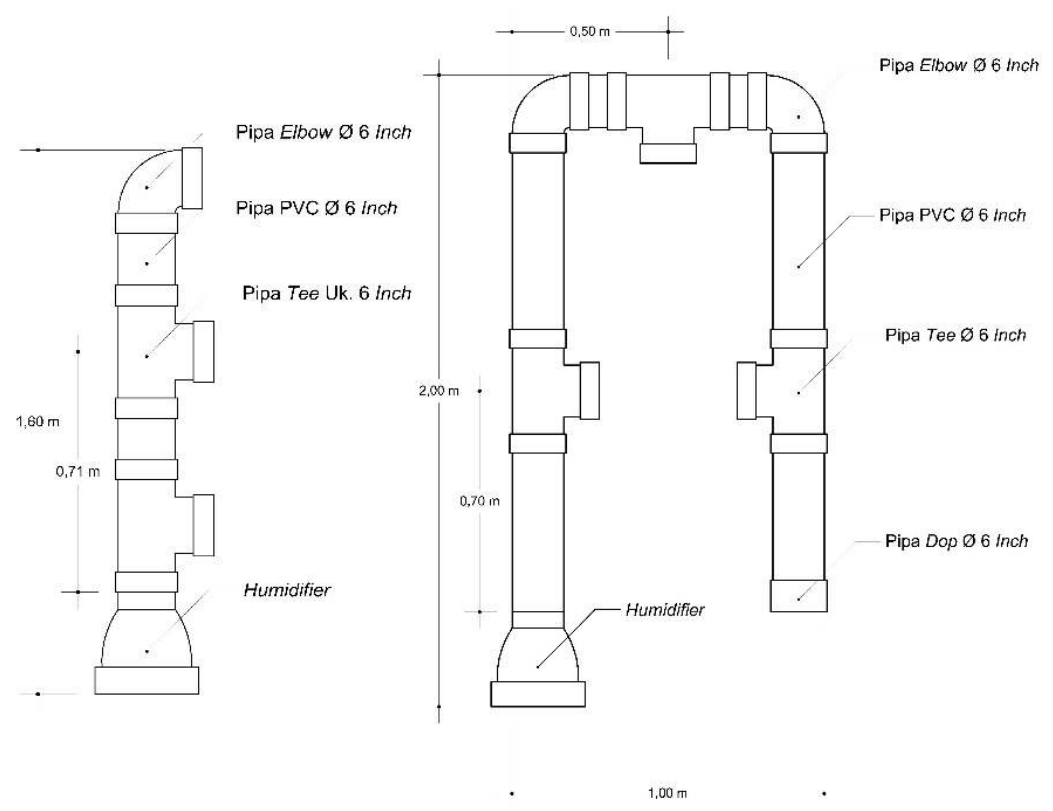

(a) (b)

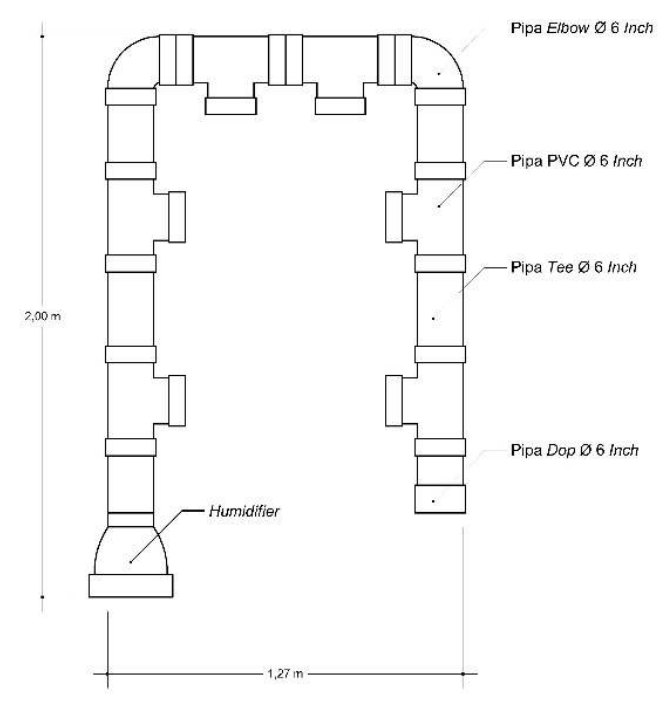

(c)

Gambar 5. Variasi Bentuk Pipa Penyalur (a) Satu Sisi (b) Melingkar Penuh (c) Melingkar Penuh dengan Jumlah Output Dua Kali (b) " [9]

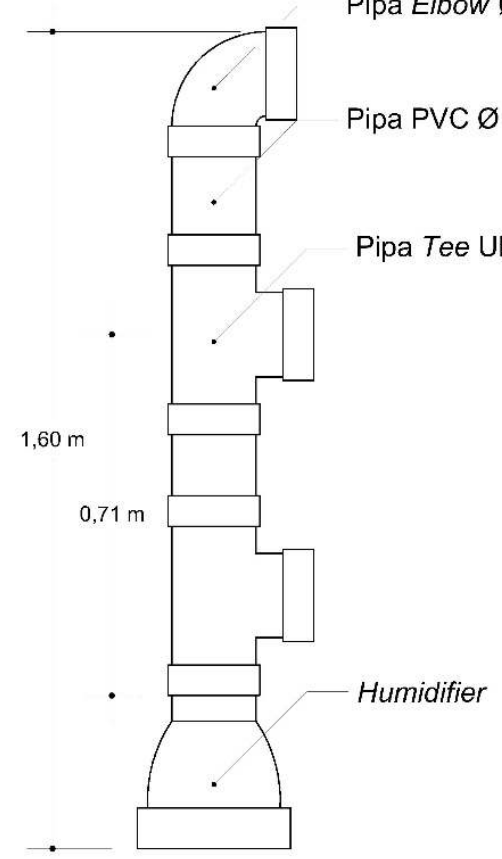

(a)

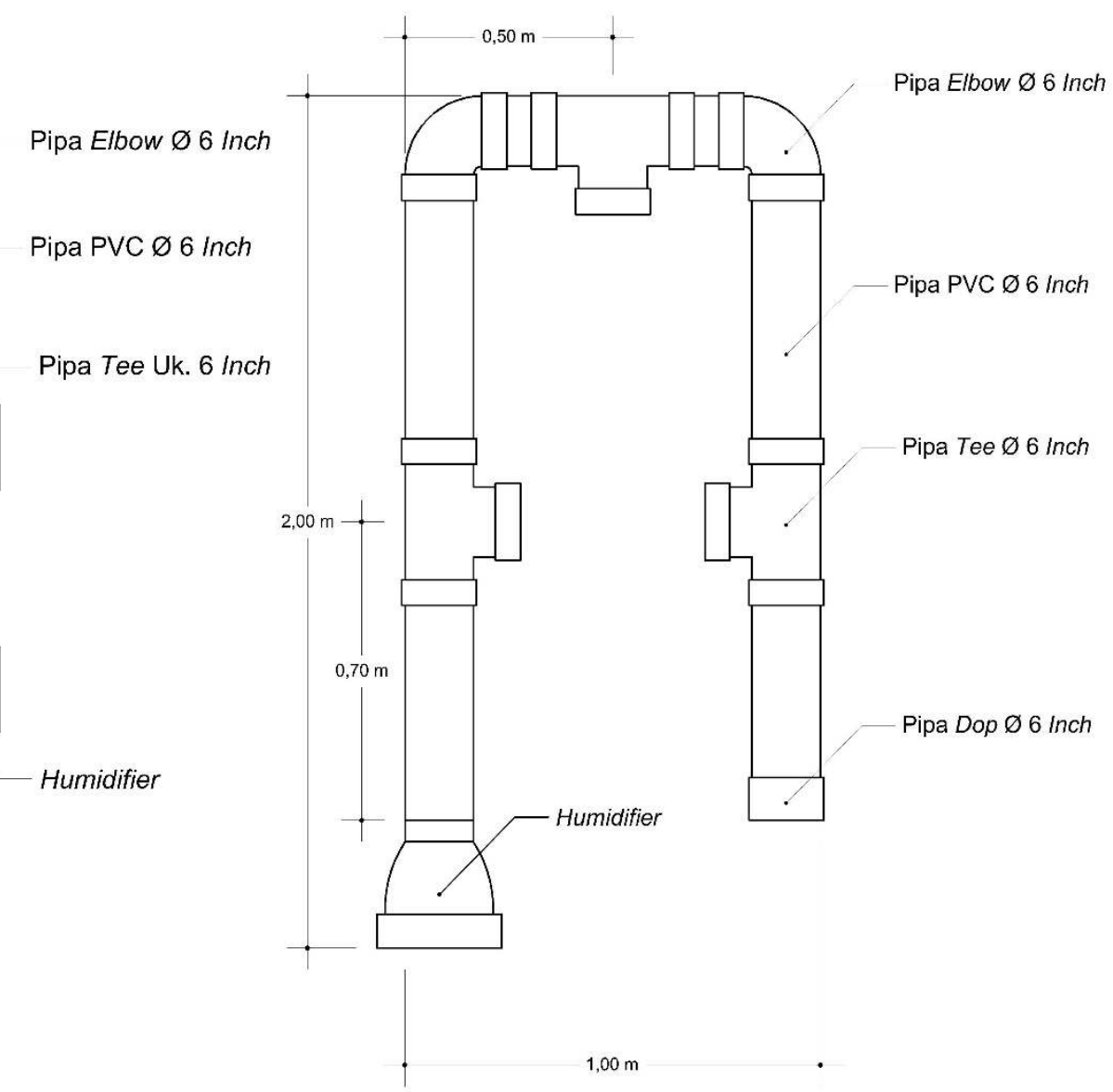

(b)

Gambar 6. Variasi Sistem Perpipaan (a) Satu Sisi Pengembunan (b) Tiga Sisi Pengembunan [9] 
Analisis rancangan terdiri dari uji fungsi dan uji kinerja. Uji fungsi dilakukan dengan mengacu pada pengujian bilik sterilisasi "White Box" berdasarkan berbagai variasi percobaan. Jika terjadi kegagalan uji fungsi, maka proses rancang bangun akan diulang dengan melakukan rancangan fungsional ulang.

Namun jika berhasil, maka dilakukan proses validasi dan kalibrasi. Proses validasi yang dilakukan meliputi : (a) Diamater pipa terhadap semburan embun humidifier; (b) Bentuk pipa penyalur terhadap semburan embun humidifier; dan (c) Panjang lintasan pipa terhadap semburan embun humidifier.

Proses kalibrasi yang dilakukan meliputi setting diameter, bentuk dan panjang lintasan yang optimal untuk humidifier tertentu. Uji kinerja dilakukan setelah lolos proses uji fungsi. Uji kinerja dilakukan setelah lolos proses uji fungsi seperti tertera di Gambar 7. Jika uji kinerja gagal, maka proses rancang bangun dilakukan pengulangan dengan melakukan uji fungsi.
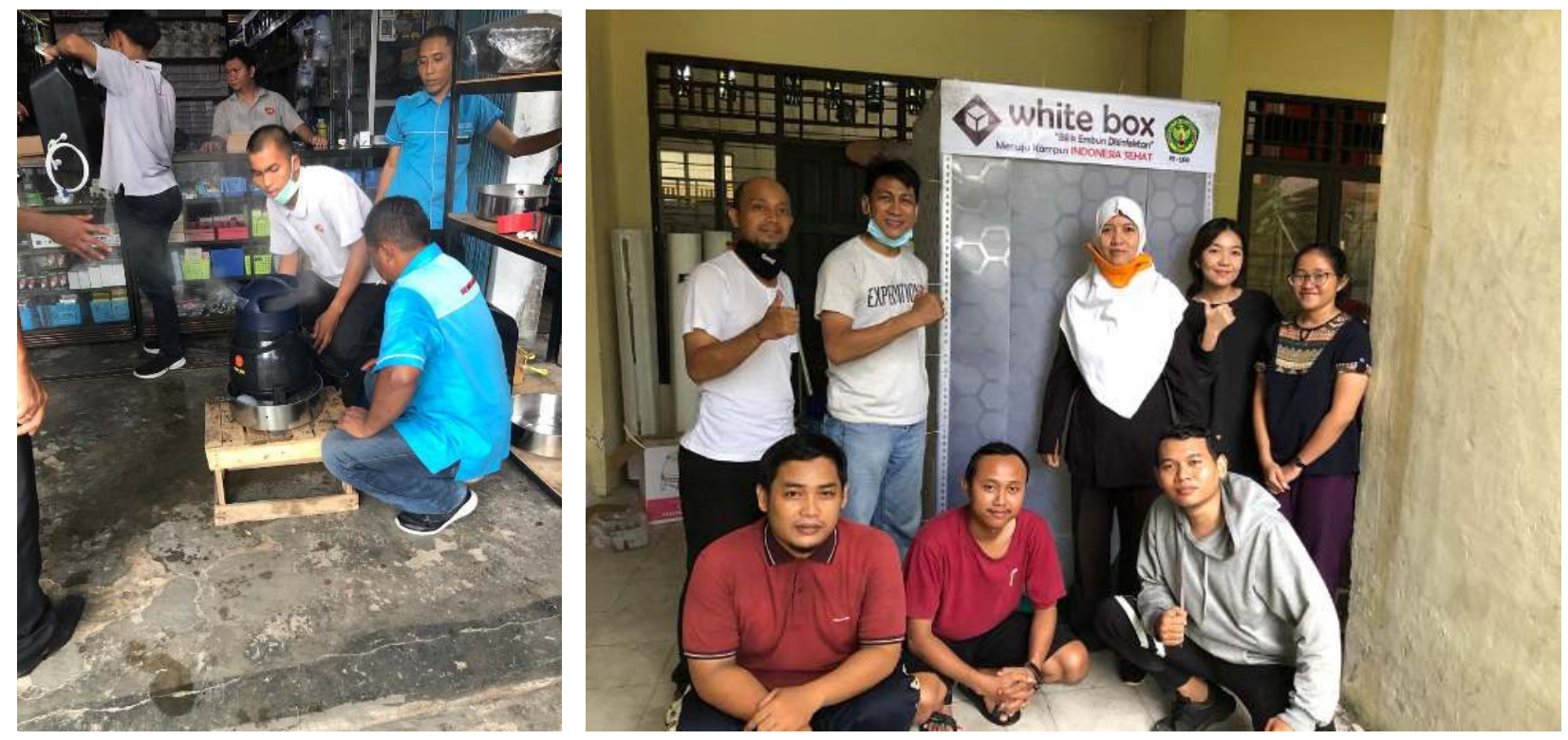

Gambar 7. Uji Fungsi dan Uji Kinerja Bilik Sterilisasi [9]

\section{Simpulan}

Berdasarkan dari studi literatur, kompilasi data, pelaksanaan penelitian, melakukan analisa, maka penelitian ini dapat disimpulkan sebagai berikut: (a) Penelitian rancang bangun sebagai alat Teknologi Tepat Guna (TTG) berupa bilik sterilisasi mempunyai keunggulan dilengkapi dengan fitur proses penyalur pengembunan dari alat humidifier untuk selanjutnya disebut bilik sterilisasi "White Box"; (b) Keunggulan pada saat pengguna masuk ke bilik sterilisasi "White Box", ada sensor gerak/halangan yang merespon dan secara otomatis menghidupkan humidifier (yang menghasilkan pengembunan) dan disalurkan ke sistem perpipaan dan dikeluarkan ke sistem lubang (outlet system) sehingga menyebar ke bilik dan mengenai seluruh tubuh pengguna; (c) Penelitian rancangan bangun bilik sterilisasi "White Box" ini dilakukan dengan tujuan fungsional melakukan optimalisasi sistem penyalur pengembunan yang dihasilkan alat humidifier; (d) Langkah kerja penelitian telah terlaksana secara runut antara lain: Tahap persiapan yaitu dengan melakukan pengumpulan data-data atau literatur tentang hasil penelitian dan publikasi yang relevan dan terkini serta mempersiapkan data peta lokasi yaitu foto udara (peta di google earth) sebagai panduan tempat lokasi penempatan hasil penelitian; Tahap pelaksanaan yaitu membuat rancangan fungsional dan rancangan struktural, Melakukan persiapan alat dan bahan dan pembuatan bilik sterilisasi serta membuat perakitan bilik sterilisasi "White Box"; dan tahap pasca pelaksanaan adalah pengujian bilik sterilisasi melalui uji fungsi dan uji kinerja bilik sterilisasi; (e) Pengujian penelitian melalui rancangan struktural bilik sterilisasi "White Box" meliputi : dimensi; bentuk, dan sistem perpipaan. Komposisi ketiga komponen rancangan struktural ini diujicobakan sehingga membentuk sebuah sistem yang optimal dalam menyalurkan pengembunan yang dihasilkan alat humidifier telah dilaksanakan. 


\section{Ucapan Terima Kasih}

Penulis mengucapkan terimakasih kepada Universitas Palangka Raya atas pendanaan penelitian DIPA PNBP Universitas Palangka Raya dengan surat kontrak No: Nomor: SP DIPA-023.17.2.677566/2020 tanggal 23 Juli 2020. Terimakasih penulis ucapkan kepada Rektor Universitas Palangka Raya yang telah memberi dukungan kepada peneliti untuk melakukan riset "white box." Terima kasih kepada mahasiswa di Jurusan/Prodi Teknik Sipil dan Mahasiswa di Jurusan/Prodi Arsitektur, Fakultas Teknik, Universitas Palangka Raya yang telah membantu dalam pelaksanaan riset "white box." Terimakasih kepada Kepala Laboratorium Hidrolika dan Hidrologi Fakultas Teknik Universitas Palangka Raya yang telah memberikan kesempatan kepada tim peneliti dalam uji fungsi dan uji kinerja "White Box."

\section{Daftar Rujukan}

[1] N. R. Yunus and A. Rezki, "Kebijakan pemberlakuan lockdown sebagai antisipasi penyebaran corona virus Covid-19," SALAM; J. Sos. Budaya Syar-i, vol. 7, no. 3, pp. 227-238, 2020, doi: $10.15408 /$ sjsbs.v7i3.15083.

[2] M. A. Pardiyanto, "Kebijakan pemerintah dalam upaya pencegahan wabah Covid 19," SPEKTRUM, vol. 17, no. 2, pp. 23-37, 2020.
[3] W. D. Suryandari, "Efektifitas kebijakan pembatasan sosial berskala besar dalam masa pandemi Corona Virus 2019 oleh pemerintah sesuai amanat UUD NKRI tahun 1945 dan PP Nomor 21 tahun 2020," J-PeHI J. Penelit. Huk. Indones., vol. 2, no. 1, pp. 31-40, 2021.

[4] Gloria, "Dosen UGM Buat Bilik Disinfektan," 2020. https://ugm.ac.id/id/berita/19188-dosen-ugmbuat-bilik-disinfektan.

[5] Y. Lee et al., "Apparatus for Both Humidification and Air Cleaning," US20170122588A1, 2017.

[6] N. Hamidah, N. D. W., T. G. Garib, and W. Nuswantoro, "Rancang Bangun Bilik Sterilisasi 'White Box' Laporan Penelitian Pengembangan Inovatif," 2020.

[7] J. . Ahn and J. E. Chang, "Air cleaning humidifier and disc assembly thereof," US 2011/0084414 A1, Sep. 10, 2011.

[8] L. Groat and D. Wang, Architectural Research Methods. New York: John Wiley \& Sons, 2000.

[9] N. Hamidah, D. . Nindito, T. G. Garib, and W. Nuswantoro, "The function of 'White Box' sterilization in anticipation of Covid-19 pandemic prevention," in The 2nd International Conference on Hazard Mitigation in Geographic and Education Perspectives (ICHMGEP) 2020, 2020, pp. 1-10. 